\title{
Monofunctional Pt(II) complexes based on 8-aminoquinoline: synthesis and pharmacological characterization
}

\author{
Facchetti Giorgio, ${ }^{a}$ Ferri Nicola,${ }^{b^{*}}$ Lupo Maria Giovanna, ${ }^{\mathbf{b}}$ Giorgio Lucchini, ${ }^{\mathbf{c}}$ Rimoldi Isabella ${ }^{\mathbf{a}^{*}}$ \\ [a] Dr. I. Rimoldi, ${ }^{*}$ http://orcid.org/0000-0002-6210-0264 Dr. G. Facchetti, http://orcid.org/0000-0002-1260-1335 \\ Dipartimento di Scienze Farmaceutiche \\ Università degli Studi di Milano \\ Via Venezian 21, 20133 Milan, Italy \\ *E-mail: isabella.rimoldi@unimi.it \\ [b] Prof. N. Ferri, ${ }^{*}$ http://orcid.org/0000-0001-8898-7441, Dr. M.G. Lupo, http://orcid.org/0000-0002-4236-4414 \\ Dipartimento di Scienze del Farmaco \\ Università degli Studi di Padova \\ Via Marzolo 5, 35131, Padua, Italy \\ *E-mail: Nicola.ferri@unipd.it \\ [c] Dr. G. Lucchini, \\ Dipartimento di Scienze Agrarie e Ambientali-Produzione, Territorio, Agroenergia epartment \\ Università degli Studi di Milano \\ Via Celoria 2, 20133 Milan, Italy
}

\begin{abstract}
Among the heterocyclic compounds, 8-aminoquinoline and its derivatives have become important candidates for the preparation of new antiproliferative metallo-drugs. Here, we reported the synthesis and cytotoxicity evaluation of a series of platinum complexes using 8aminoquinoline and its chiral 5,6,7,8-tetrahydro-derivatives as chelating ligands. In the proposed complexes, a differently and opportunely alkylated imidazole was used to prepare the corresponding monofunctional platinum complexes. The preliminary cytotoxicity evaluation was carried out on the highly aggressive MDA-MB-231, invasive and poorly differentiated triple-negative breast cancer (TNBC) cell line, furnishing a significant $\mathrm{IC}_{50} 10.9 \pm 1.3 \mu \mathrm{M}$ for Pt-IV. This series of complexes revealed an induction of $\mathrm{p53}$, interfering with the progression of the G0/G1 phase of the cell cycle.
\end{abstract}

\section{Introduction}

8-aminoquinoline and its derivatives are heterocyclic compounds that are drawing attention in the field of coordination chemistry due to their metal-binding ability along with a variety of biological effects. ${ }^{[1]}$ Known for their recognised antimalarial properties, 8aminoquinoline analogues such as sitamaquine and NPC1161 are currently investigated for their antileishmanial and antitrypanosomal activities. ${ }^{[2]}$ More recently, an increasing number of 8-aminoquinoline related compounds have been investigated as anticancer agents for their ability to trigger different antiproliferative effects such as the inhibition of tyrosine kinases, tubulin polymerization, topoisomerase and DNA mechanisms of repair. ${ }^{[3]}$ From a structural point of view, the presence of two nitrogen donor atoms make them bidentate chelating ligands able to form thermodynamically stable coordinative complexes with metal ions providing them with novel biochemical properties. ${ }^{[4]}$ Thus, 8-aminoquinolines are beheld as a privileged framework for the preparation of new metallodrug candidates. A recent paper ${ }^{[5]}$ reported the use of $N$-(quinoline-8-yl)quinolin-8-sulfonamide as ligand for the synthesis of a copper (II) complex endowed with intercalation properties and the ability to trigger DNA fragmentation and apoptosis in Jurkat T cells. ${ }^{[6]}$ Additionally, a series of transition metal complexes of mixed ligands 8-aminoquine-5-substituted uracil bases have been investigated for their cytotoxicity showing a significant activity against MOLT-3 cancer cells. ${ }^{[7]}$ Based on these premises and considering that the anticancer potential of platinum (II) 8-aminoquinolines complexes has been poorly explored, 8-aminoquinoline scaffold has been selected for the preparation of monofunctional platinum complexes. ${ }^{[8]}$ This class of anticancer agents, bearing just one substitution-labile ligand, has recently emerged for their unconventional mechanisms of action compared to cisplatin-like drugs, their potent cytotoxic activity and their distinctive anticancer spectrum of action. Although there is a certain interaction with DNA double helix, cationic platinum complexes stood out for their ability to affect different cell targets becoming a potential tool for the treatment of aggressive and/or orphan cancers. Moreover, the cellular uptake of the cationic monofunctional platinum complexes by the organic cation transporters (OCTs) could provide an opportunity for a selective delivery to tumours known for overexpressing these channels, such as the human colorectal cancer. ${ }^{\text {[9] }}$

Our research group have recently reported a series of cationic platinum complexes obtained by the addition of an alkylated imidazole ligand to the dichloride neutral precursor led to charged platinum compounds. This series showed a novel cytotoxic profile involving mechanisms of action not related to a simple DNA crosslinking as established for cisplatin. The so-synthesised cationic platinum compounds displayed a potent anticancer effect on different cancer cell lines known for their poor sensitivity to cisplatin chemotherapy. ${ }^{[10]}$

In the present study, we reported the synthesis and cytotoxicity evaluation of a series of platinum complexes using 8-aminoquinoline and its chiral 5,6,7,8-tetrahydro-derivatives ${ }^{[11]}$ as chelating ligands and in which different alkylated imidazoles were used to prepare the corresponding monofunctional platinum complexes.

\section{Results and Discussion}


In previous works, two different series of platinum compounds bearing $\mathrm{N}$-alkyl aminomethyl-imidazole ligands were synthetized. Both the series, dichloride and cationic ones, were evaluated for their in vitro cytotoxic activity, with the cationic compounds having the best results in terms of cytotoxicity. $\left.{ }^{[4 a}, 10 a, 12\right]$ Considering the favourable introduction of a differently substituted alkyl-imidazole as additional monocoordinated ligand to form the monofunctional cationic platinum (II) complexes, the choice to conserve this moiety and instead to modify the bidentate ligands was applied, with the aim to verify the effect of the bidentate ligands on the biological activity. The synthesis of platinum compounds, bearing the commercially available 8-aminoquinoline L1 as ligand, proceeded as reported in Figure 1.

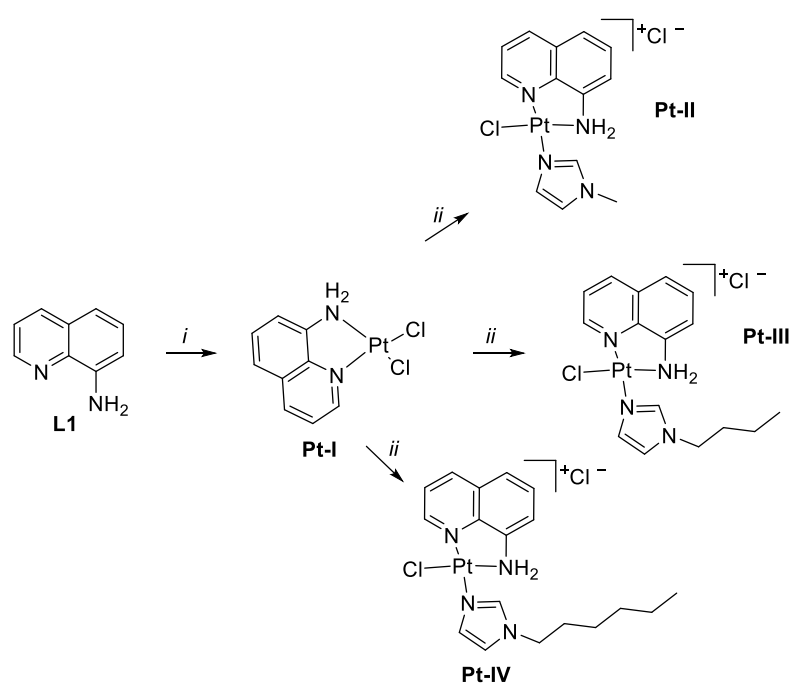

Figure 1. Synthesis of Pt I-IV. Reagents and Conditions: i) $\mathrm{K}_{2} \mathrm{PtCl}_{4}, \mathrm{H}_{2} \mathrm{O}$, reflux for $18 \mathrm{~h}$; ii) Alkyl-imidazole, $\mathrm{DMF}, 55^{\circ} \mathrm{C} 18 \mathrm{~h}$.

The complexes were fully characterized by ${ }^{1} \mathrm{H}-\mathrm{NMR},{ }^{13} \mathrm{C}-\mathrm{NMR},{ }^{195} \mathrm{Pt}-\mathrm{NMR}$, elemental analysis and ESI-MS. With the aim to verify the correct conformation of the complexes, and considering that only one stereoisomer was formed during the synthesis, as evinced by NMR spectroscopy and by RP-HPLC, 2D-NMR experiment (NOESY) was performed for complex Pt-IV. (spectrum reported in SI) The presence of the only one cross-peak between the $H$ in 2 position and $H$ in 3 position on pyridine ring confirmed that the imidazole moiety was stereoselectively coordinated in trans to the nitrogen of pyridine as designed for all the complexes in the Figure 1.

Considering the possibility to selectively reduce the aromatic ring of the pyridine or the phenolic one, ligands L2, L3 and L4 were synthetized. In particular, the ligands $\mathbf{L} 3$ and $\mathbf{L} 4$, being respectively the $S$ and $R$ enantiomers of a tetrahydroquinoline, called CAMPY, were resolved and synthetized as previously reported. ${ }^{[11]}$ (Figure 2) The corresponding platinum compounds Pt-VI-XI, were fully characterized as for Pt-IIV and the chemical structures were again confirmed by NOESY experiments.

The determination of $\log P_{\text {ow }}$ was evaluated for all the platinum complexes by RP-HPLC, equipped with $\mathrm{C} 18$ ODS at $25^{\circ} \mathrm{C}$ with water/methanol in ratio $80 / 20$ in presence of $\mathrm{HCOOH} 15 \mathrm{mM}$ as eluent, and using commercially available platinum complexes as references. ${ }^{[13]}$ The values were generally comparable, in a range of $0.65-1.51$, depending on the type of the aromaticity of the bidentate ligands and on the length of the alkyl chain on imidazole monodentate ligand.

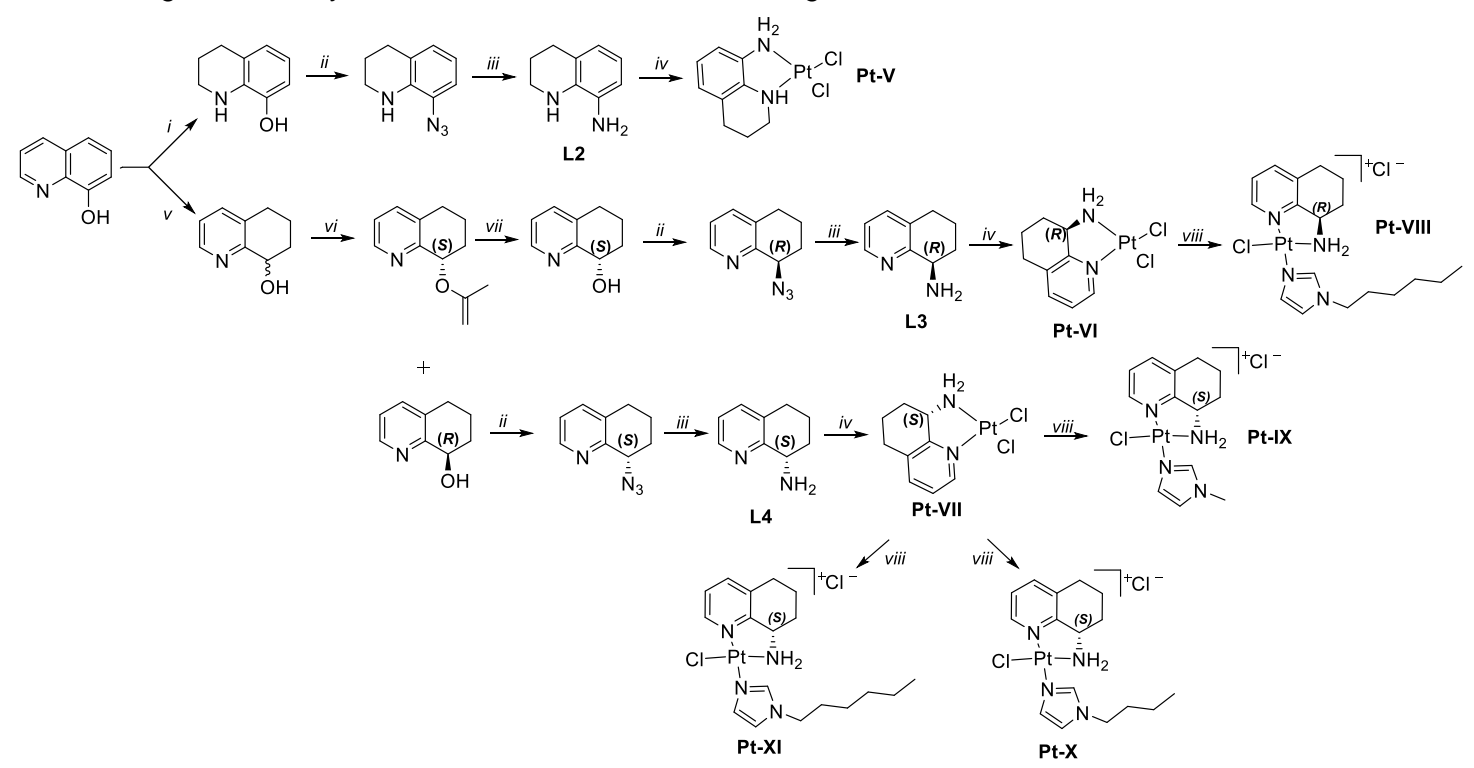


Figure 2. Synthesis of Pt-V-XI. Reagents and Conditions: i) $\mathrm{PtO}_{2} 10 \%, \mathrm{H}_{2}$ (5 atm), $\mathrm{CF}_{3} \mathrm{CCOH}, 4 \mathrm{~h}$; ii) $\mathrm{MsCl}, \mathrm{DMAP}, \mathrm{CH}_{2} \mathrm{Cl}$, $\mathrm{DMSO}, 18 \mathrm{~h}$; iii) $\mathrm{Pd} / \mathrm{C} 5 \%$, $\mathrm{H}_{2}$ (10 atm), $\mathrm{MeOH}, 4 \mathrm{~h}$; iv) $\mathrm{K}_{2} \mathrm{PtCl}_{4}, \mathrm{H}_{2} \mathrm{O}$, reflux for $18 \mathrm{~h}$; v) $\mathrm{PtO}_{2} 5 \%, \mathrm{H}_{2}(5 \mathrm{~atm}), \mathrm{CF}_{3} \mathrm{CCOH}, 4 \mathrm{~h}$; vi) vinyl acetate, Cal. B Lipase, mol. sieves $4 \AA$, diisopropyl ether, $60^{\circ} \mathrm{C}, 30 \mathrm{~h}$; vii) $\mathrm{K}_{2} \mathrm{CO}_{3}, \mathrm{MeOH}$, reflux, 2h; viii) Alkyl-imidazole, DMF, $55^{\circ} \mathrm{C} 18 \mathrm{~h}$.

The cytotoxicity of platinum (II) complexes on triple negative breast cancer MDA-MB-231 cell line was tested in vitro by sulforhodamine $\mathrm{B}$ (SRB) assay. After $48 \mathrm{~h}$ incubation with increasing concentration of the compounds, the $\mathrm{IC}_{50}$ values were determined. As shown in Table 1, all the complexes significantly reduced, by more than $50 \%$, the cell viability with $\mathrm{IC}_{50}$ values ranging from $4.5 \pm 0.5 \mu \mathrm{M}(\mathrm{Pt}-\mathrm{I})^{[14}$ up to $195.8 \pm 27.9 \mu \mathrm{M}$ (Pt-VII). Importantly, the cytotoxic effects of the most active compounds, were confirmed by MTT assay (Table 1).

Table 1. Cytotoxic effects of tested platinum (II) complexes on MDA-MB-231.

\begin{tabular}{lllll}
\hline Complex & $\begin{array}{l}\text { LogP } \\
\text { (RP-HPLC) }\end{array}$ & $\begin{array}{l}\text { IC50 } \\
\text { (SRB assay) } \\
\text { MDA-MB-231 }\end{array}$ & $\begin{array}{l}\text { IC }_{50} \\
\text { (MTT assay) } \\
\text { MDA-MB-231 }\end{array}$ & $\begin{array}{l}\text { IC } 50 \\
\text { A27 assay) } \\
\text { A2780 }\end{array}$ \\
\hline Cisplatin & $-2.21^{[15]}$ & $59.4 \pm 10.06$ & $31.5 \pm 4.9$ & \\
\hline Pt-I & 1.51 & $4.5 \pm 0.5$ & $4.4 \pm 0.6$ & \\
\hline Pt-II & 1.18 & $48.8 \pm 0.6$ & & \\
\hline Pt-III & 1.22 & $22.5 \pm 2.0$ & & \\
\hline Pt-IV & 1.38 & $10.9 \pm 1.3$ & $16.6 \pm 2.3$ & \\
\hline Pt-V & 1.3 & $41.0 \pm 11.8$ & & $16.3 \pm 1.5$ \\
\hline Pt-VI & 0.89 & $123.4 \pm 21.3$ & & \\
\hline Pt-VII & 0.88 & $195.8 \pm 27.9$ & & \\
\hline Pt-VIII & 0.97 & $95.5 \pm 13.5$ & $105.0 \pm 16.4$ & \\
\hline Pt-IX & 0.65 & $119.1 \pm 20.2$ & & \\
\hline Pt-X & 0.76 & $94.9 \pm 4.8$ & & \\
\hline Pt-XI & 0.98 & $60.5 \pm 7.8$ & $80.0 \pm 10.6$ & \\
\hline
\end{tabular}

To extend this observation we investigated the cytotoxic effects of the most promising cationic pyridine complexes, such as Pt-IV, PtVIII and Pt-XI, on A2780 ovarian cell line. As reported in Table 1, Pt-IV appeared to elicit a similar cytotoxic effect on both cell lines, while the two enantiomers Pt-VIII and Pt-XI show a more potent cytotoxic effect on A2780 compared to MDA-MB-231, as indicated by lower $\mathrm{IC}_{50}$ values.

To investigate the molecular mechanism of the cytotoxic effect observed with Pt-IV, Pt-VIII and Pt-XI, we performed a cell cycle analysis and determined the expression levels of $\mathrm{p} 53$ and proliferating cell nuclear antigen (PCNA). Cisplatin was utilized as positive control. Pt-VIII and Pt-XI determined a significant accumulation of proliferating MDA-MB-231 cells into G0/G1 cell line with a concomitant reduction of $\mathrm{G} 2 / \mathrm{M}$.
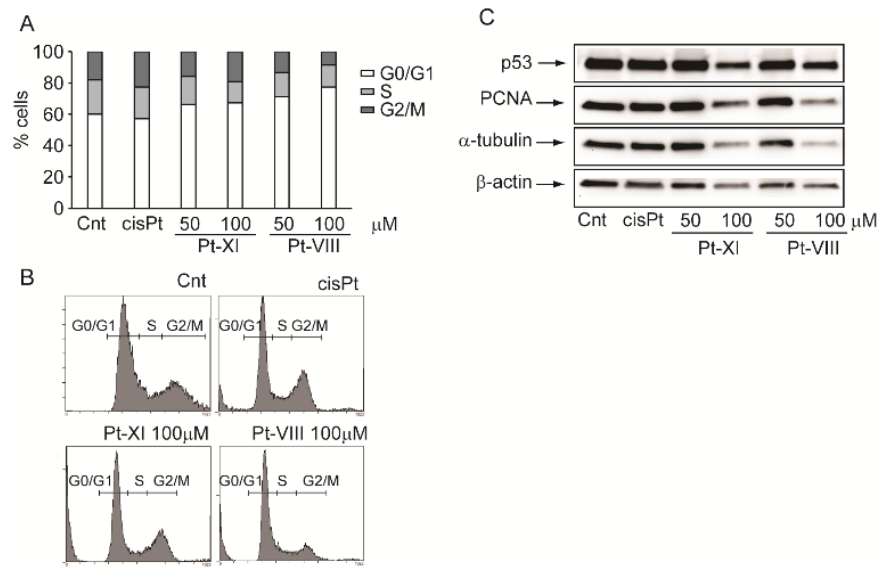

Figure 3. Effect of Pt-VIII and Pt-XI on cell cycle progression of MDA-MB-231 cell line. The cells were incubated for $24 \mathrm{~h}$ with indicated concentrations of tested compounds, then cell cycle analysis was performed and expression of p53, PCNA, $\alpha$-tubulin and $\beta$-actin were evaluated by western blot analysis. CisPt: cisplatin Cnt: control. 
This effect is concentration dependent and appears to be different than cisplatin that slightly reduced the percentage of cells in G0/G1. By western blot analysis, we observed a drastic reduction of p53 and PCNA levels after incubation of the cells with $100 \mu \mathrm{M}$ concentration of Pt-VIII and Pt-XI. Surprisingly, also the intracellular levels of housekeeping proteins, such as $\alpha$-tubulin and $\beta$-actin, were significantly reduced in response to both compounds. These data indicate that the platinum (II) complexes may affect translational processes. (Figure 3)

Similar effect was also observed with the more potent complex, Pt-IV (Figure 4). The accumulation of cells in the G0/G1 phase was observed at 10-15 $\mu \mathrm{M}$ and at similar concentration (12.5-25 $\mu \mathrm{M})$ a significant reduction of p53, PCNA and $\beta$-actin were observed.
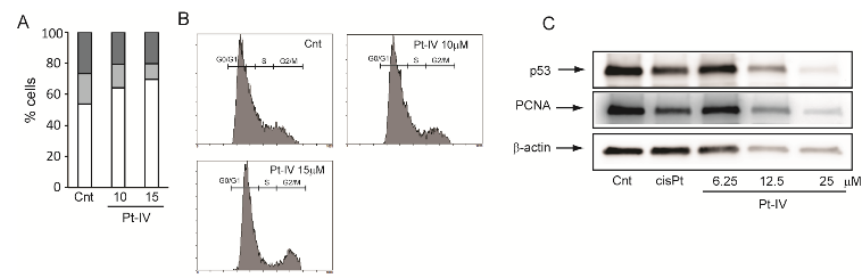

Figure 4. Effect of Pt-IV on cell cycle progression of MDA-MB-231 cell line. The cells were incubated for $24 \mathrm{~h}$ with indicated concentrations of tested compounds, then cell cycle analysis was performed and expression of p53, PCNA, $\alpha$-tubulin and $\beta$-actin were evaluated by western blot analysis. CisPt: cisplatin; Cnt: control.

This observation prompted us to investigate the effect of these complexes on mRNA levels of p53. As expected, cisplatin significantly induced p53 mRNA by 3.9 \pm 1.3 fold (Figure 5). Both Pt-VIII and Pt-XI showed a similar induction at the same concentration than cisplatin $(100 \mu \mathrm{M}), 2.7 \pm 1.0$ and $3.1 \pm 0.1$ fold, respectively. However, the most impressive induction of p53 mRNA (11.3 \pm 1.7 fold) was observed in response to $25 \mu \mathrm{M}$ of Pt-IV. These data suggested that all the complexes induce p53 mRNA and that Pt-IV appears to be the more potent and more efficient on this cellular response. The induction of p53 indicate the nuclear DNA as a potential site of action of platinum (II) complexes. Thus, the cellular uptake was investigated by monitoring the platinum concentrations by ICP-MS from a total cell extract or DNA isolated from MDA-MB-231 incubated for $3 \mathrm{~h}$ with complexes and cisplatin as reference drug.

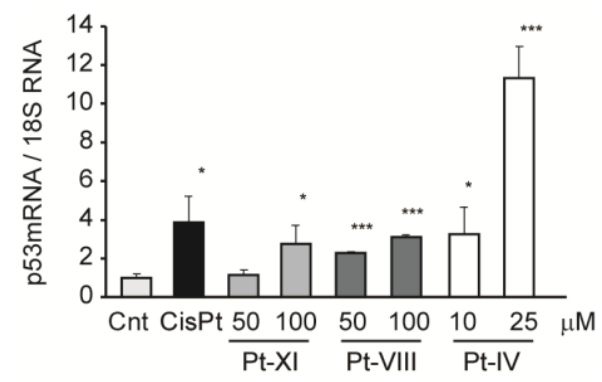

Figure 5. Effect of platinum (II) complexes on p53 expression in MDA-MB-231 cell line. Cells were seeded (250,000/35 mm petri dish) and incubated with DMEM supplemented with $10 \%$ FCS; $24 \mathrm{~h}$ later the medium was replaced with one containing $10 \%$ FCS and the reported concentrations of complexes and cisplatin and the incubation was continued for a further $24 \mathrm{~h}$. At the end of this incubation period the total RNA was extracted and mRNA p53 expression evaluated by real-time PCR reaction and normalized with $18 S$. ${ }^{*} p<0.05 ;{ }^{* *} p<0.001$.

Interestingly, all three platinum (II) complexes accumulate at much higher concentration into the cells compared to cisplatin, suggesting a more efficient cell membrane permeability (Figure 6A). The intracellular concentration of Pt-IV was 13.7-fold higher than cisplatin, although the amount of ${ }^{195} \mathrm{Pt}$ recovered from DNA samples of MDA-MB-231 cell lines exposed for $3 \mathrm{~h}$ to these complexes was significantly lower than cisplatin (Figure 6B). However, it must be considered that Pt-IV was utilized at four-fold lower concentration than cisplatin $(25 \mu \mathrm{M}$ vs $100 \mu \mathrm{M})$. Thus, it is tempting to speculate that the amount of Pt-IV that reached the DNA was proportionally higher than Pt-VIII and Pt-XI.

A

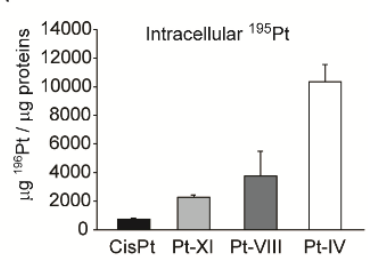

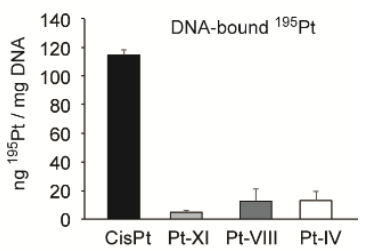

Figure 6. DNA-bound and total intracellular concentrations of ${ }^{195} \mathrm{Pt}$ after incubation of MDA-MB-231 cell line with platinum (II) complexes and cisplatin. Cells were seeded (250,000/35 mm petri dish) and incubated with DMEM supplemented with $10 \% \mathrm{FCS} ; 24 \mathrm{~h}$ later the medium was replaced with one containing $10 \%$ FCS and complexes or cisplatin at $100 \mu \mathrm{M}$ concentration, except for Pt-IV that was utilized at $25 \mu \mathrm{M}$ in DNA samples. The incubation was continued for $3 \mathrm{~h}$ at $37{ }^{\circ} \mathrm{C}$. At the end of this incubation period, the DNA was extracted, and cell homogenates prepared. Total, $(\mathrm{A})$ and DNA-bound (B) ${ }^{195} \mathrm{Pt}$ concentrations were then determined by ICP-MS and the values corrected for protein and DNA contents. 


\section{Conclusions}

In conclusion, the change in diamine ligand (8-aminequinoline vs 2-methyl-aminoimidazole) drastically modified the biological performance of the corresponding cationic platinum (II) complexes despite the same alkyl-imidazole moiety. These differences are evident not only in their accumulation in different cellular phase but also in the significant effect on mRNA levels of p53, on $\alpha$-tubulin and on $\beta$-actin. In particular, these results suggest that Pt-IV is the most potent cytotoxic agent of this series of platinum (II) complexes and that it may act by interacting to the nuclear DNA as confirmed by accumulation data (ICP-MS). However, further analyses are required to better define its molecular mechanism of action.

\section{Experimental Section}

All manipulations involving air sensitive materials were carried out in an inert atmosphere glove box or using standard Schlenk line techniques, under an atmosphere of nitrogen or argon in oven-dried glassware. All solvents were used anhydrous. ${ }^{1} \mathrm{H}-\mathrm{NMR}$, ${ }^{13} \mathrm{C}-\mathrm{NMR}$ and ${ }^{195} \mathrm{Pt}-\mathrm{NMR}$ spectra were recorded on a Bruker DRX Avance $300 \mathrm{MHz}$ equipped with a non-reverse probe (BBI) and also on a Bruker DRX Avance $600 \mathrm{MHz}$ using as external reference $\mathrm{K}_{2} \mathrm{PtCl}_{4}$. MS analyses were performed by using a Thermo Finnigan (MA, USA) LCQ Advantage system MS spectrometer with an electrospray ionisation source and an 'Ion Trap' mass analyser. The MS spectra were obtained by direct infusion of a sample solution in $\mathrm{MeOH}$ under ionisation, ESI positive. Elemental analyses were performed using

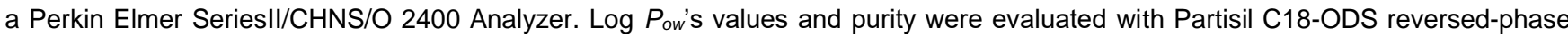
HPLC column with Merck-Hitachi L-7100 equipped with Detector UV6000LP. ICP-MS data were recorded with BRUKER aurora M90 ICP-MS (MA, USA). Quinolin-8-amine (L1) is commercially available. (R)- and (S)-5,6,7,8-tetrahydroquinolin-8-amine (L3 and L4 respectively) were synthesized according to the procedure reported in literature. ${ }^{[11 a, 16]}$

Synthesis of (L2): To a solution of quinolin-8-amine ( $1 \mathrm{mmol}, 144 \mathrm{mg})$ and $\mathrm{NiCl}_{2} 6 \mathrm{H}_{2} \mathrm{O}(0.5 \mathrm{mmol}, 138 \mathrm{mg})$ in methanol $(10 \mathrm{~mL}), \mathrm{NaBH}_{4}$ $(4 \mathrm{mmol}, 151 \mathrm{mg})$ was added portion wise under cooling for 30 minutes, then the stirring was continued for other 30 minutes at room temperature. The solvent was removed in vacuo and the crude product was purified by flash chromatography (hexane/ethyl acetate 7:3) to afford $\mathbf{L} 2$ as a yellow oil. After dissolving the oil in acetone, $\mathrm{HCl} 4 \mathrm{M}$ (2 equiv.) was added and upon layering diethyl ether the product was precipitated as a purple solid corresponding to the L2-dichloride salt.

3.1.1 8-Amino-1,2,3,4-tetrahydroquinoline (L2). Pinkish solid (128 mg, 87\% yield). ${ }^{1} \mathrm{H}$ NMR (300 MHz, CDCl $\left.3-\mathrm{d}\right) \delta 6.53-6.59$ (m, 3H), 3.33 (t, $J=5.4 \mathrm{~Hz}, 2 \mathrm{H}), 3.23(\mathrm{~s}, 2 \mathrm{H}), 2.77(\mathrm{t}, J=6.3 \mathrm{~Hz}, 2 \mathrm{H}), 1.92(\mathrm{q}, J=6.3 \mathrm{~Hz}, 2 \mathrm{H}) \mathrm{ppm} ;{ }^{13} \mathrm{C} \mathrm{NMR}\left(75 \mathrm{MHz}, \mathrm{CDCl} \mathrm{N}_{3}-\mathrm{d}\right) \delta 134.59$, $131.50,126.33,117.40,118.33,113.05,39.88,26.23,23.11 ; \mathrm{MS}(\mathrm{ESI}+): \mathrm{m} / \mathrm{z} 149.22[\mathrm{M}+\mathrm{H}]^{+}$

3.2 General procedure for the synthesis of Pt-I, Pt-V, Pt-VI and Pt-VII

Potassium tetrachloroplatinate $(1 \mathrm{mmol})$ was dissolved in $10 \mathrm{~mL}$ of distilled water in a Schlenk tube under nitrogen atmosphere and to this $1 \mathrm{mmol}$ of the diamine ligand was added. The mixture was acidified with $\mathrm{HCl} 6 \mathrm{M}$ (8 equiv.) and heated under reflux overnight. After cooling to room temperature, the product was collected as a differently coloured solid, washed extensively with water followed by small amounts of diethyl ether and dried under vacuum.

3.2.1 (8-Aminoquinoline)dichloroplatinum(II) Pt-I: brown solid (87\% yield). ${ }^{1} \mathrm{H}$ NMR (300 MHz, DMF- $\left.\mathrm{d}_{7}\right) \delta 9.67(\mathrm{dd}, J=5.3,1.3 \mathrm{~Hz}, 1 \mathrm{H})$, $8.94(\mathrm{dd}, J=8.4,1.3 \mathrm{~Hz}, 1 \mathrm{H}), 8.09(\mathrm{dd}, J=21.3,7.5 \mathrm{~Hz}, 2 \mathrm{H}), 7.96-7.64(\mathrm{~m}, 2 \mathrm{H}), 4.02(\mathrm{brs}, 2 \mathrm{H}) \mathrm{ppm} ;{ }^{13} \mathrm{C} \mathrm{NMR}\left(75 \mathrm{MHz}, \mathrm{DMF}-\mathrm{d}_{7}\right) \delta$ $149.12,148.90,141.99,138.72,130.72,129.11,128.23,127.53,123.74$ ppm; ${ }^{195} \mathrm{Pt}$ NMR $\left(300 \mathrm{MHz}\right.$, DMF- $\mathrm{d}_{7}$ ) $\delta-2106$ ppm; Elemental analysis of $\mathrm{C}_{9} \mathrm{H}_{8} \mathrm{Cl}_{2} \mathrm{~N}_{2} \mathrm{Pt}$ : calcd. C, 26.36; $\mathrm{H}, 1.97 ; \mathrm{N}, 6.83$; found $\mathrm{C}, 26.87 ; \mathrm{H}, 2.06 ; \mathrm{N}, 6.94 ; \mathrm{MS}(\mathrm{ESI}+): \mathrm{m} / z 409.23[\mathrm{M}+\mathrm{H}]^{+}$

3.2.2 (8-Amino-1,2,3,4-tetrahydroquinoline)dichloroplatinum(II) Pt-V: brown solid (72\% yield). ${ }^{1} \mathrm{H}$ NMR $\left(300 \mathrm{MHz}, \mathrm{DMF}_{-} \mathrm{d}_{7}\right) \delta 8.62-$ $8.28(\mathrm{~m}, 1 \mathrm{H}), 8.16-8.03(\mathrm{~m}, 2 \mathrm{H}), 7.74-7.53(\mathrm{~m}, 2 \mathrm{H}), 7.47(\mathrm{~d}, J=6.4 \mathrm{~Hz}, 1 \mathrm{H}), 4.67-4.20(\mathrm{~m}, 1 \mathrm{H}), 3.46-3.23(\mathrm{~m}, 3 \mathrm{H}), 3.24-2.95$ $(\mathrm{m}, 1 \mathrm{H}), 2.69-2.46(\mathrm{~m}, 1 \mathrm{H}), 2.42-2.25(\mathrm{~m}, 1 \mathrm{H}) \mathrm{ppm} ;{ }^{13} \mathrm{C}$ NMR $\left(75 \mathrm{MHz}, \mathrm{DMF}-\mathrm{d}_{7}\right) \delta$ 145.52, 141.75, 134.44, 128.23, 128.12, 123.26, 49.10, 24.49, 22.06 ppm; ${ }^{195} \mathrm{Pt}$ NMR (300 MHz, DMF-d $) \delta-2239$ ppm; Elemental analysis of $\mathrm{C}_{9} \mathrm{H}_{11} \mathrm{Cl}_{2} \mathrm{~N}_{2} \mathrm{Pt}$ : calcd. C, 26.10; $\mathrm{H}, 2.92$; $\mathrm{N}, 6.76$; found C, 26.28; $\mathrm{H}, 2.99 ; \mathrm{N}, 6.69 ; \mathrm{MS}(\mathrm{ESI}+): \mathrm{m} / \mathrm{z} 412.46[\mathrm{M}+\mathrm{H}]^{+}$

3.2.3 ((R)-8-Amino-5,6,7,8-tetrahydroquinoline)dichloroplatinum(II) Pt-VI: olive green solid (46\% yield). ${ }^{1} \mathrm{H} \mathrm{NMR}\left(300 \mathrm{MHz}, \mathrm{DMF}-\mathrm{d}_{7}\right) \delta$ $9.08(\mathrm{~d}, J=5.3 \mathrm{~Hz}, 1 \mathrm{H}), 7.99(\mathrm{~d}, J=7.8 \mathrm{~Hz}, 1 \mathrm{H}), 7.59-7.28(\mathrm{~m}, 1 \mathrm{H}), 6.52$ (brs, $1 \mathrm{H}), 5.71$ (brs, $1 \mathrm{H}), 4.64-4.23(\mathrm{~m}, 1 \mathrm{H}), 2.92-2.80$ $(\mathrm{m}, 2 \mathrm{H}), 2.45-2.36(\mathrm{~m}, 1 \mathrm{H}), 2.12-1.71(\mathrm{~m}, 3 \mathrm{H}) \mathrm{ppm} ;{ }^{13} \mathrm{C} \mathrm{NMR}\left(75 \mathrm{MHz}, \mathrm{DMF}-\mathrm{d}_{7}\right) \delta 145.91,139.01,138.72,136.57,124.73,61.45$, 27.08, 26.90, 21.56 ppm; ${ }^{195} \mathrm{Pt}$ NMR (300 MHz, DMF-d $) \delta-2145$ ppm; Elemental analysis of $\mathrm{C}_{9} \mathrm{H}_{12} \mathrm{Cl}_{2} \mathrm{~N}_{2} \mathrm{Pt}$ : calcd. C, 26.10; $\mathrm{H}, 2.92$; $\mathrm{N}, 6.76$; found C, 26.40; H, 2.97; N, 6.64; MS (ESI+): $\mathrm{m} / \mathrm{z} 413.71[\mathrm{M}]^{+}$

3.2.4 ((S)-8-Amino-5,6,7,8-tetrahydroquinoline)dichloroplatinum(II) Pt-VII: yellow green solid (48\% yield). ${ }^{1} \mathrm{H} \mathrm{NMR}\left(300 \mathrm{MHz}, \mathrm{DMF}-\mathrm{d}_{7}\right)$ $\delta 9.10(\mathrm{~d}, J=5.3 \mathrm{~Hz}, 1 \mathrm{H}), 7.99(\mathrm{~d}, J=7.8 \mathrm{~Hz}, 1 \mathrm{H}), 7.57-7.26(\mathrm{~m}, 1 \mathrm{H}), 6.54$ (brs, 1H), 5.71 (brs, $1 \mathrm{H}), 4.67-4.21(\mathrm{~m}, 1 \mathrm{H}), 2.93-2.80$ $(\mathrm{m}, 2 \mathrm{H}), 2.45-2.38(\mathrm{~m}, 1 \mathrm{H}), 2.12-1.71(\mathrm{~m}, 3 \mathrm{H}) \mathrm{ppm} ;{ }^{13} \mathrm{C} \mathrm{NMR}\left(75 \mathrm{MHz}, \mathrm{DMF}-\mathrm{d}_{7}\right) \delta 145.92,139.05,138.72,136.59,124.71,61.48$, 27.08, 26.93, 21.56 ppm; ${ }^{195} \mathrm{Pt}$ NMR (300 MHz, DMF-d $) \delta-2143$ ppm; Elemental analysis of $\mathrm{C}_{9} \mathrm{H}_{12} \mathrm{Cl}_{2} \mathrm{~N}_{2} \mathrm{Pt}$ : calcd. C, 26.10; $\mathrm{H}, 2.92$; $\mathrm{N}, 6.76$; found C, 26.33; H, 3.01; N, 6.57; MS (ESI+): $\mathrm{m} / \mathrm{z} 377.78[\mathrm{M}-\mathrm{Cl}]^{+}$ 3.3 General procedure for the synthesis of Pt-II, Pt-III, Pt-IV, Pt-VIII, Pt-IX, Pt-X and Pt-XI

To a stirred solution in anhydrous DMF (1 mL) of the selected platinum dichloride complex (Pt-I, Pt-VI or Pt-VII, $1 \mathrm{mmol}$ ) the appropriate substituted $\mathrm{N}$-alkyl imidazole $(0.9 \mathrm{mmol})$ was added and the reaction mixture was warmed at $55{ }^{\circ} \mathrm{C}$ overnight under a nitrogen atmosphere. The solvent was then removed in vacuo and the oily residue was dissolved in dry methanol. After filtration of any eventually formed precipitate on a Celite pad, the solution was concentrated to give the crude product as an oil that upon washing with diethyl ether afforded the desired complex as a differently coloured powder.

3.3.1 (8-Aminoquinoline)(1-methyl-1H-imidazole)chloroplatinum(II) chloride Pt-II: deep red solid (24\% yield). ${ }^{1} \mathrm{H} \mathrm{NMR}(300 \mathrm{MHz}$, $\left.\mathrm{CD}_{3} \mathrm{OD}-\mathrm{d}_{4}\right) \delta 9.50-9.45(\mathrm{~d}, 1 \mathrm{H}), 8.86-8.79(\mathrm{~m}, 1 \mathrm{H}), 8.36(\mathrm{t}, J=12.1 \mathrm{~Hz}, 1 \mathrm{H}), 8.08-7.92(\mathrm{~m}, 2 \mathrm{H}), 7.88-7.57(\mathrm{~m}, 1 \mathrm{H}), 7.51(\mathrm{~s}, 1 \mathrm{H})$, $7.40-7.35(\mathrm{~m}, 1 \mathrm{H}), 7.33-7.29(\mathrm{~m}, 1 \mathrm{H}), 3.89(\mathrm{~s}, 3 \mathrm{H}) \mathrm{ppm} ;{ }^{13} \mathrm{C} \mathrm{NMR}\left(75 \mathrm{MHz}, \mathrm{CD}_{3} \mathrm{OD}-\mathrm{d}_{4}\right) \delta 150.49,147.58,140.39,139.49,139.15$, 
130.24, 129.23, 128.28, 127.73, 123.68, 123.30, 122.64, 34.22 ppm; ${ }^{195} \mathrm{Pt}$ NMR $\left(300 \mathrm{MHz}, \mathrm{CD}_{3} \mathrm{OD}-\mathrm{d}_{4}\right) \delta-2429$ ppm; Elemental analysis of $\mathrm{C}_{13} \mathrm{H}_{14} \mathrm{Cl}_{2} \mathrm{~N}_{4} \mathrm{Pt}$ : calcd. C, 31.72; $\mathrm{H}, 2.87 ; \mathrm{N}, 11.38$; found $\mathrm{C}, 32.02 ; \mathrm{H}, 3.01 ; \mathrm{N}, 11.87 ; \mathrm{MS}(\mathrm{ESI}+): \mathrm{m} / \mathrm{z} 420.92$ [M-Cl] ${ }^{+}$ 3.3.2 (8-Aminoquinoline)(1-buthyl-1H-imidazole)chloroplatinum(II) chloride Pt-III: deep red solid (62\% yield). $1 \mathrm{H} \mathrm{NMR} \mathrm{(300} \mathrm{MHz,}$ $\left.\mathrm{CD}_{3} \mathrm{OD}-\mathrm{d}_{4}\right) \delta 9.49(\mathrm{~d}, J=4.7 \mathrm{~Hz}, 1 \mathrm{H}), 8.70(\mathrm{~d}, J=8.2 \mathrm{~Hz}, 1 \mathrm{H}), 8.03-7.94(\mathrm{~m}, 3 \mathrm{H}), 7.75-7.63(\mathrm{~m}, 2 \mathrm{H}), 7.44(\mathrm{~d}, 2 \mathrm{H}), 7.34(\mathrm{~s}, 1 \mathrm{H})$, $4.25-4.11(\mathrm{~m}, 2 \mathrm{H}), 1.89-1.80(\mathrm{~m}, 2 \mathrm{H}), 1.48-1.23(\mathrm{~m}, 2 \mathrm{H}), 1.02-0.94(\mathrm{~m}, 3 \mathrm{H}) \mathrm{ppm} ;{ }^{13} \mathrm{C} \mathrm{NMR}\left(75 \mathrm{MHz}, \mathrm{CD}_{3} \mathrm{OD}-\mathrm{d}_{4}\right) \delta 150.46,148.10$, $140.41,139.48,139.30,130.08,128.76,127.79,127.54,123.28,122.86,120.59,32.34,19.17,19.12,12.42 \mathrm{ppm} ;{ }^{195} \mathrm{Pt} \mathrm{NMR}(300 \mathrm{MHz}$ $\left.\mathrm{CD}_{3} \mathrm{OD}-\mathrm{d}_{4}\right) \delta-2348$ ppm; Elemental analysis of $\mathrm{C}_{16} \mathrm{H}_{20} \mathrm{Cl}_{2} \mathrm{~N}_{4} \mathrm{Pt}$ : calcd. C, 35.96; $\mathrm{H}, 3.77 ; \mathrm{N}, 10.49$; found $\mathrm{C}, 36.37 ; \mathrm{H}, 3.98 ; \mathrm{N}, 10.44 ;$ MS (ESI+): $m / z 498.91[\mathrm{M}]^{+}$

3.3.3 (8-Aminoquinoline)(1-hexyl-1H-imidazole)chloroplatinum(II) chloride Pt-IV: purple solid (59\% yield). $1 \mathrm{H} \mathrm{NMR} \mathrm{(300} \mathrm{MHz,} \mathrm{CD} \mathrm{OD}_{3}$ $\left.\mathrm{d}_{4}\right) \delta 9.49(\mathrm{~d}, J=4.7 \mathrm{~Hz}, 1 \mathrm{H}), 8.71(\mathrm{~d}, J=8.3 \mathrm{~Hz}, 1 \mathrm{H}), 8.03-7.88(\mathrm{~m}, 2 \mathrm{H}), 7.79-7.62(\mathrm{~m}, 3 \mathrm{H}), 7.44(\mathrm{~s}, 1 \mathrm{H}), 7.38(\mathrm{~s}, 1 \mathrm{H}), 4.40-3.99$ $(\mathrm{m}, 2 \mathrm{H}), 1.93-1.85(\mathrm{~m}, 2 \mathrm{H}), 1.68-1.14(\mathrm{~m}, 6 \mathrm{H}), 1.08-0.66(\mathrm{~m}, 3 \mathrm{H}) \mathrm{ppm} ;{ }^{13} \mathrm{C}$ NMR $\left(75 \mathrm{MHz}, \mathrm{CD}_{3} \mathrm{OD}-\mathrm{d}_{4}\right) \delta 150.44,148.09,140.38$, $139.47,130.21,130.08,129.21,128.77,128.51,127.81,127.54,122.85,49.23,30.93,29.74,25.70,22.13,12.91 \mathrm{ppm}$; ${ }^{25} \mathrm{Pt} \mathrm{NMR}$ $\left(300 \mathrm{MHz}, \mathrm{CD}_{3} \mathrm{OD}-\mathrm{d}_{4}\right) \delta-2324$ ppm; Elemental analysis of $\mathrm{C}_{18} \mathrm{H}_{24} \mathrm{Cl}_{2} \mathrm{~N}_{4} \mathrm{Pt}$ : calcd. C, 38.44; $\mathrm{H}, 4.30 ; \mathrm{N}, 9.96$; found $\mathrm{C}, 38.68 ; \mathrm{H}, 4.79$; $\mathrm{N}, 10.21 ; \mathrm{MS}(\mathrm{ESI}+): \mathrm{m} / \mathrm{z} 526.95[\mathrm{M}]^{+}$

3.3.4 ((R)-8-amino-5,6,7,8-tetrahydroquinoline)(1-hexyl-1H-imidazole)chloroplatinum(II) chloride Pt-VIII: brown solid (46\% yield). $1 \mathrm{H}$ $\operatorname{NMR}\left(300 \mathrm{MHz}, \mathrm{CD}_{3} \mathrm{OD}-\mathrm{d}_{4}\right) \delta 9.04(\mathrm{~d}, J=5.3 \mathrm{~Hz}, 1 \mathrm{H}), 8.00(\mathrm{~d}, J=7.4 \mathrm{~Hz}, 1 \mathrm{H}), 7.51(\mathrm{~s}, 1 \mathrm{H}), 7.40-7.30(\mathrm{~m}, 2 \mathrm{H}), 7.10(\mathrm{~s}, 1 \mathrm{H}), 4.53-$ $4.51(\mathrm{~m}, 1 \mathrm{H}), 4.31-3.95(\mathrm{~m}, 2 \mathrm{H}), 3.10-2.90(\mathrm{~m}, 2 \mathrm{H}), 2.38-2.34(\mathrm{~m}, 1 \mathrm{H}), 2.20-1.57(\mathrm{~m}, 5 \mathrm{H}), 1.31-1.28(\mathrm{~m}, 6 \mathrm{H}), 0.90-0.88(\mathrm{~m}$, $3 \mathrm{H}) \mathrm{ppm} ;{ }^{13} \mathrm{C} \mathrm{NMR}\left(75 \mathrm{MHz}, \mathrm{CD}_{3} \mathrm{OD}-\mathrm{d}_{4}\right) \delta 161.68,146.17,140.75,137.16,125.03,124.33,122.21,121.30,60.39,48.27,30.83,30.20$, 29.37, 26.41, 25.64, 22.09, 21.19, 12.86 ppm; ${ }^{195} \mathrm{Pt} \mathrm{NMR}\left(300 \mathrm{MHz}, \mathrm{CD}_{3} \mathrm{OD}-\mathrm{d}_{4}\right) \delta-2471 \mathrm{ppm}$; Elemental analysis of $\mathrm{C}_{18} \mathrm{H}_{28} \mathrm{Cl}_{2} \mathrm{~N}_{4} \mathrm{Pt}_{\mathrm{t}}$ calcd. C, 38.17; H, 4.98; N, 9.89; found C, 38.56; H, 4.78; N, 9.95; MS (ESI+): $\mathrm{m} / \mathrm{z} 530.94[\mathrm{M}]^{+}$

3.3.5 ((S)-8-Amino-5,6,7,8-tetrahydroquinoline)(1-methyl-1H-imidazole)chloroplatinum(II) chloride Pt-IX: dark-red solid (42\% yield). $1 \mathrm{H}$ $\operatorname{NMR}\left(300 \mathrm{MHz}, \mathrm{CD}_{3} \mathrm{OD}-\mathrm{d}_{4}\right) \delta 8.32(\mathrm{~s}, 1 \mathrm{H}), 8.00(\mathrm{~d}, J=7.8 \mathrm{~Hz}, 1 \mathrm{H}), 7.61(\mathrm{~d}, J=6.20 \mathrm{~Hz}, 1 \mathrm{H}), 7.43-7.39(\mathrm{~m}, 1 \mathrm{H}), 7.32(\mathrm{~s}, 1 \mathrm{H}), 7.06$ $(\mathrm{s}, 1 \mathrm{H}), 4.51-4.47(\mathrm{~m}, 1 \mathrm{H}), 3.82(\mathrm{~s}, 3 \mathrm{H}), 2.98-2.86(\mathrm{~m}, 2 \mathrm{H}), 2.40-2.35(\mathrm{~m}, 1 \mathrm{H}), 2.12-2.08(\mathrm{~m}, 1 \mathrm{H}), 1.91-1.88(\mathrm{~m}, 2 \mathrm{H}) \mathrm{ppm} ;{ }^{13} \mathrm{C}$ NMR $\quad\left(75 \mathrm{MHz}, \quad \mathrm{CD}_{3} \mathrm{OD}-\mathrm{d}_{4}\right) \quad \delta \quad 161.66, \quad 151.12, \quad 140.81, \quad 138.56, \quad 134.60, \quad 127.83, \quad 125.09, \quad 116.09, \quad 60.34$, 47.86, 33,81, 29.39, 21.03; ${ }^{195} \mathrm{Pt} \mathrm{NMR}\left(300 \mathrm{MHz}, \mathrm{CD}_{3} \mathrm{OD}-\mathrm{d}_{4}\right) \delta-2412 \mathrm{ppm}$; Elemental analysis of $\mathrm{C}_{13} \mathrm{H}_{18} \mathrm{Cl}_{2} \mathrm{~N}_{4} \mathrm{Pt}$ : calcd. C, $31.46 ; \mathrm{H}$, $3.66 ; \mathrm{N}, 11.29$; found $\mathrm{C}, 31.11 ; \mathrm{H}, 3.97 ; \mathrm{N}, 11.13 ; \mathrm{MS}(\mathrm{ESI}+): \mathrm{m} / \mathrm{z} 424.00$ [M-Cl] $^{+}$

3.3.6 ((S)-8-Amino-5,6,7,8-tetrahydroquinolin)(1-buthyl-1H-imidazole)chloroplatinum(II) chloride Pt-X: brown solid (53\% yield). $1 \mathrm{H}$ NMR $\left(300 \mathrm{MHz}, \mathrm{CD}_{3} \mathrm{OD}-\mathrm{d}_{4}\right) \delta 9.02(\mathrm{~d}, 1 \mathrm{H}), 8.27(\mathrm{~s}, 1 \mathrm{H}), 8.00(\mathrm{~d}, J=7.3 \mathrm{~Hz}, 1 \mathrm{H}), 7.51(\mathrm{~s}, 1 \mathrm{H}), 7.46-7.33(\mathrm{~m}, 2 \mathrm{H}), 7.10(\mathrm{~s}, 1 \mathrm{H}), 4.57$ $-4.51(\mathrm{~m}, 1 \mathrm{H}), 4.28-4.07(\mathrm{~m}, 2 \mathrm{H}), 3.06-2.83(\mathrm{~m}, 2 \mathrm{H}), 2.43-2.38(\mathrm{~m}, 1 \mathrm{H}), 2.18-1.92(\mathrm{~m}, 1 \mathrm{H}), 1.96-1.75(\mathrm{~m}, 4 \mathrm{H}), 1.45-1.20$ $(\mathrm{m}, 2 \mathrm{H}), 1.06-0.84(\mathrm{~m}, 3 \mathrm{H}) \mathrm{ppm} ;{ }^{13} \mathrm{C}$ NMR $\left(75 \mathrm{MHz}, \mathrm{CD}_{3} \mathrm{OD}-\mathrm{d}_{4}\right) \delta 161.65,146.23,140.74,139.94,137.14,128.44,125.05,122.19$, 60.39, 47.87, 32.15, 29.37, 26.35, 21.07, 19.10, $12.37 \mathrm{ppm} ;{ }^{195} \mathrm{Pt}$ NMR (300 MHz, $\left.\mathrm{CD}_{3} \mathrm{OD}-\mathrm{d}_{4}\right) \delta-2468$ ppm; Elemental analysis of $\mathrm{C}_{16} \mathrm{H}_{24} \mathrm{Cl}_{2} \mathrm{~N}_{4} \mathrm{Pt}$ : calcd. C, 35.70; H, 4.49; N, 10.41; found C, 35.13; H, 4.97; N, 10.57; MS (ESI+): m/z 503.89 [M] $]^{+} ; 467.07[\mathrm{M}-\mathrm{Cl}]^{+}$

3.3.7 ((S)-8-amino-5,6,7,8-tetrahydroquinoline)(1-hexyl-1H-imidazole)chloroplatinum(II) chloride Pt-XI: brown solid (58\% yield). $1 \mathrm{H}$ $\operatorname{NMR}\left(300 \mathrm{MHz}, \mathrm{CD}_{3} \mathrm{OD}-\mathrm{d}_{4}\right) \delta 9.03(\mathrm{~d}, 1 \mathrm{H}), 8.03(\mathrm{~d}, J=7.4 \mathrm{~Hz}, 1 \mathrm{H}), 7.52(\mathrm{~s}, 1 \mathrm{H}), 7.42-7.33(\mathrm{~m}, 2 \mathrm{H}), 7.09(\mathrm{~s}, 1 \mathrm{H}), 4.57-4.50(\mathrm{~m}$, $1 \mathrm{H}), 4.24-4.04(\mathrm{~m}, 2 \mathrm{H}), 3.07-2.78(\mathrm{~m}, 2 \mathrm{H}), 2.43-2.39(\mathrm{~m}, 1 \mathrm{H}), 2.22-1.65(\mathrm{~m}, 5 \mathrm{H}), 1.38-1.25(\mathrm{~m}, 6 \mathrm{H}), 0.92-0.83(\mathrm{~m}, 3 \mathrm{H}) \mathrm{ppm}$; ${ }^{13} \mathrm{C}$ NMR $\left(75 \mathrm{MHz}, \mathrm{CD}_{3} \mathrm{OD}-\mathrm{d}_{4}\right) \delta 161.63,146.22,140.73,137.13,125.00,124.31,122.25,121.31,60.43,48.23,30.79,30.23,29.33$, 26.45, 25.63, 22.13, 21.16, 12.83 ppm; $\left.{ }^{195} \mathrm{Pt} \mathrm{NMR} \mathrm{(300} \mathrm{MHz,} \mathrm{CD}_{3} \mathrm{OD}-\mathrm{d}_{4}\right) \delta-2473 \mathrm{ppm}$; Elemental analysis of $\mathrm{C}_{18} \mathrm{H}_{28} \mathrm{Cl}_{2} \mathrm{~N}_{4} \mathrm{Pt}$ : calcd. C, 38.17; H, 4.98; N, 9.89; found C, 38.53; H, 4.83; N, 9.91; MS (ESI+): $\mathrm{m} / \mathrm{z} 531.00$ [M] $^{+} ; 495.12[\mathrm{M}-\mathrm{Cl}]^{+}$

3.4 Log $P_{\text {ow }}$ determination. RP-HPLC analysis were performed to correlate the hydrophobicity of the platinum (II) complexes with their retention time. The chromatograms were registered using Partisil C18-ODS reversed-phase HPLC column, at $25^{\circ} \mathrm{C}$ and with water/methanol in ratio $80 / 20$ in presence of $\mathrm{HCOOH} 15 \mathrm{mM}$ as mobile phase and using $\mathrm{KI}$ as internal standard (flow rate of $1 \mathrm{~mL} / \mathrm{min}$, $\lambda=210 \mathrm{~nm}$ ). The calibration curve was realized in comparison with reference compounds, chosen in commercially available platinum compounds series (i.e. cisplatin, oxaliplatin and carboplatin).

3.5 Biological evaluation procedures.

3.5.1 Reagents. Eagle's minimum essential medium (MEM) was purchased from Sigma Aldrich, while trypsin-EDTA, penicillin, streptomycin, sodium pyruvate, non-essential amino acid solution, fetal calf serum (FCS), plates and Petri dishes were purchased from EuroClone. The platinum(II) complexes were dissolved in dimethyl sulfoxide (DMSO) before performing each experiment. The maximal concentration utilized was $200 \mu \mathrm{M}$; cisplatin was tested up to $100 \mu \mathrm{M}$. The amount of DMSO did not exceed the $0.25 \%$ of the culture media volume.

3.5.2 Cell culture. Human triple negative cancer, MDA-MB-231, and ovarian carcinoma cell line, A2780, were cultured in DMEM supplemented with $10 \% \mathrm{FCS}$, non-essential amino acids, and penicillin/streptomycin at $37^{\circ} \mathrm{C}$ in a humidified atmosphere $(5 \% \mathrm{CO} 2$ and $95 \%$ air).

3.5.3 Cell viability assay. Sulphorhodamine B (SRB) assay was performed to assess the cell viability after treatments. $5 \times 103$ cells/well were seeded in a 96 -well tray in triplicate. After $24 \mathrm{~h}$ of incubation, the cells were treated with different concentrations of compounds. SRB assay were performed after $48 \mathrm{~h}$ as previously described [17]. The determination of the conversion of MTT (3-(4,5-dimethyl-2thiazolyl)-2,5-diphenyl-2H-tetrazolium bromide) to formazan was determined as previously described [18].

3.5.4 Retrotranscription and quantitative PCR (RT-qPCR). RNA Preparation and Quantitative Real Time PCR-Total RNA was extracted with the iScriptTM RT-qPCR Sample Preparation Buffer (BIO-RAD) cDNA synthesis preparation reagents (Bio-Rad) according to manufacturer's instructions. Reverse transcription-polymerase first-strand cDNA synthesis was performed by using the Maxima First Strand cDNA Synthesis Kit (Thermo Scientific) ${ }^{[17]}$. qPCR was then performed by using the PowerUpTM SYBRTM Green Master Mix (Thermo Scientific) and specific primers for the selected genes. The primer sequences used for qPCR analysis were: p53 Forward 5'GGAGGTTGTGAGGCGCTGG-3' Reverse 5'-CACGCACCTCAAAGCTGTTC-3'; 18S Forward 5'-CTCAACACGGGAAACCTCAC-3' Reverse 5'-CGCTCCACCAACTAAGAACG-3'[17]. The analyses were performed with the Mx3000P qPCR System (Agilent), with the following cycling conditions: $95^{\circ} \mathrm{C}, 2 \mathrm{~min} ; 95^{\circ} \mathrm{C}, 15 \mathrm{sec}$ and $60^{\circ} \mathrm{C}, 1 \mathrm{~min}$ for $40 \mathrm{cycles}$. Data were expressed as $\mathrm{Ct}$ values and used for 
the relative quantification of targets with the $\Delta \Delta \mathrm{Ct}$ calculation. The $\Delta \Delta \mathrm{Ct}$ were correct by multiplying the ratio value between the efficiency of specific primers and housekeeping $18 \mathrm{~S}$. The efficiency was calculated as $\left(\left(10^{\wedge}(-1 / \text { slope })\right)-1\right)^{\star} 100$.

3.5.5 Western blot analysis. Cells were washed twice with PBS and lysed with a solution of $50 \mathrm{mM} \mathrm{Tris} \mathrm{pH} 7.5,150 \mathrm{mM} \mathrm{NaCl}, 0.5 \%$ Nonidet-P40, containing protease and phosphatase inhibitor cocktails (SIGMA, Milan, Italy) for 30 min. on ice. Twenty $\mu \mathrm{g}$ of proteins and a molecular mass marker (Thermo Scientific) were separated on 4-12\% SDS-PAGE (BIO-RAD) under denaturing and reducing conditions. Proteins were then transferred to a nitrocellulose membrane by using the Trans-Blot $\AA$ Turbo ${ }^{\mathrm{TM}}$ Transfer System (BIO-RAD). Membranes were washed with Tris-buffered saline-Tween 20 (TBS-T), and nonspecific binding sites were blocked in TBS-T containing $5 \%$ nonfat dried milk for $60 \mathrm{~min}$ at room temperature. Blots were incubated overnight at $4{ }^{\circ} \mathrm{C}$ with a diluted solution (5\% nonfat dried milk) of the following human primary antibodies: anti-p53 (mouse monoclonal antibody, sigma; dilution 1:5000), anti PCNA (mouse monoclonal, sigma; dilution 1:1,000), anti- $\alpha$-tubulin (mouse monoclonal antibody, Sigma clone DM1A; dilution 1:2,000) and anti $\beta$-actin (mouse monoclonal antibody, Sigma; dilution 1:2,000). Membranes were washed with TBS-T and then exposed for 90 min at room temperature to a diluted solution ( $5 \%$ nonfat dried milk) of the secondary antibodies (peroxidase-conjugate goat anti-rabbit, and antimouse, Jackson Immunoresearch). Immunoreactive bands were detected by exposing the membranes to ClarityTM Western ECL chemiluminescent substrates (Bio-Rad) for $5 \mathrm{~min}$, and images were acquired with a VersaDoc 4000 Imaging System (Bio-Rad) [19]. Densitometric readings were evaluated using the ImageLabTM software as previously described.

3.5.6 Determination of intracellular and DNA-bound ${ }^{195} \mathrm{Pt}$ concentration. For the determination of total intracellular ${ }^{195} \mathrm{Pt}$ concentrations, cells were washed twice with PBS and lysed by incubation with $1 \%$ Triton X100/0.1\% SDS for 5 min at room temperature. Cell lysates were then cleared by centrifugation at $14,000 \mathrm{~g}$ for $10 \mathrm{~min}$, and the ${ }^{195} \mathrm{Pt}$ concentrations determined by ICP-MS. The data were normalized with the protein concentrations determined using the BCA protein assay. For the DNA-bound ${ }^{195} \mathrm{Pt}$ concentrations, the nuclear DNA was extracted by incubating cell monolayers with digest buffer (50 mM Tris- $\mathrm{HCl} 1 \mathrm{M}, 100 \mathrm{mM} \mathrm{NaCl}, 100 \mathrm{mM} \mathrm{EDTA}, 1 \%$ SDS) then transferred to $1.5 \mathrm{~mL}$ microcentrifuge tubes and saturated $\mathrm{NaCl}$ solution added. The samples were then clear by centrifugation for $15 \mathrm{~min}$ at $13,000 \mathrm{rpm}$ and the supernatant transferred to new microcentrifuge tubes and DNA precipitated by isopropanol. DNA was then washed by centrifugation two times with $70 \%$ ethanol and resuspended in TE buffer (10 mM Tris pH 8.0 ; $0.1 \mathrm{mM}$ EDTA). The ${ }^{195} \mathrm{Pt}$ concentrations were then determined by ICP-MS.

3.5.7 Statistical analysis. Experimental data are expressed as mean \pm SD of at least three independent experiments. The effects of the complexes versus control were analyzed by two-tailed Student's $t$ test for unpaired data. The concentration of compounds required to reduce by $50 \%$ of cell viability $\left(\mathrm{IC}_{50}\right)$ was calculated by nonlinear regression curve (GraphPad Prism, Version 5.01).

Keywords: 8-amino-5,6,7,8-tetrahydroquinoline• Alkyl-imidazole• Cationic platinum (II) complex • Triple negative breast cancer • Monofunctional metallo-drugs.

\section{References:}

[1] a) V. Oliveri, G. Vecchio, Eur. J. Med. Chem. 2016, 120, 252-274; b) S. Jain, V. Chandra, P. Kumar Jain, K. Pathak, D. Pathak, A. Vaidya, Arabian Journal of Chemistry 2016.

[2] a) K. S. Phopin, N.; Treeratanapiboon, L.; Kunwittaya, S.; Prachayasittikul, S.; Ruchirawat, S.; Prachayasittikul, V. , EXCL/ 2016, 144-152; b) L. R. Chiarelli, M. Mori, D. Barlocco, G. Beretta, A. Gelain, E. Pini, M. Porcino, G. Mori, G. Stelitano, L. Costantino, M. Lapillo, D. Bonanni, G. Poli, T. Tuccinardi, S. Villa, F. Meneghetti, Eur. J. Med. Chem. 2018, 155, 754-763.

[3] a) G. Gakhar, T. Ohira, A. Shi, D. H. Hua, T. A. Nguyen, Drug Development Research 2008, 69, 526-534; b) A. Casado-Sánchez, C. Martín-Santos, J. M. Padrón, R. Mas-Ballesté, C. Navarro-Ranninger, J. Alemán, S. Cabrera, J. Inorg. Biochem. 2017, 174, 111-118.

[4] a) N. Ferri, G. Facchetti, S. Pellegrino, E. Pini, C. Ricci, G. Curigliano, I. Rimoldi, Bioorg Med Chem 2015, 23, 2538-2547; b) F. Porta, G. Facchetti, N. Ferri, A. Gelain, F. Meneghetti, S. Villa, D. Barlocco, D. Masciocchi, A. Asai, N. Miyoshi, S. Marchianò, B.-M. Kwon, Y. Jin, V. Gandin, C. Marzano, I. Rimoldi, Eur. J. Med. Chem. 2017, 131, 196-206; c) Z.-F. Chen, X.-Y. Song, Y. Peng, X. Hong, Y.-C. Liu, H. Liang, Dalton Trans. 2011, 40, 1684-1692; d) Y.-C. Liu, X.-Y. Song, Z.-F. Chen, Y.-Q. Gu, Y. Peng, H. Liang, Inorg. Chim. Acta 2012, 382, 52-58; e) Y.-C. Liu, Z.-F. Chen, X.-Y. Song, Y. Peng, Q.-P. Qin, H. Liang, Eur. J. Med. Chem. 2013, 59, 168-175; f) P. Y. L. Chung, P.L.; Zhou, Y.; Gasparello, J.; Finotti, A.; Chilin, A.; Marzaro, G.; Gambari, R.; Bian, Z.; Kwok, W.M.; Wong, W.Y.; Wang, X.; Lam, A.K.-Y.; Chan, A.S.-C.; Li, X.; Ma, J.Y.W.; Chui, C.H.; Lam, K.H.; Tang, J.C.O. , Cells 2018, 7.

[5] A. Pascual-Álvarez, T. Topala, F. Estevan, F. Sanz, G. Alzuet-Piña, Eur. J. Inorg. Chem. 2016, 2016, $982-994$.

[6] a) S. Tardito, A. Barilli, I. Bassanetti, M. Tegoni, O. Bussolati, R. Franchi-Gazzola, C. Mucchino, L. Marchiò, J. Med. Chem. 2012, 55, 10448-10459; b) S. Zhang, C. Tu, X. Wang, Z. Yang, J. Zhang, L. Lin, J. Ding, Z. Guo, Eur. J. Inorg. Chem. 2004, 2004, 4028-4035; c) H.-L. Chen, C.-Y. Chang, H.-T. Lee, H.H. Lin, P.-J. Lu, C.-N. Yang, C.-W. Shiau, A. Y. Shaw, Bioorg. Med. Chem. 2009, 17, 7239-7247; d) Y.-H. Kim, K.-J. Shin, T. G. Lee, E. Kim, M.-S. Lee, S. H. Ryu, P.-G. Suh, Biochem. Pharm. 2005, 69, 1333-1341.

[7] a) Y.-C. Liu, J.-H. Wei, Z.-F. Chen, M. Liu, Y.-Q. Gu, K.-B. Huang, Z.-Q. Li, H. Liang, Eur. J. Med. Chem. 2013, 69, 554-563; b) P. Ratchanok, W. Apilak, P. Veda, P. Supaluk, R. Somsak, P. Virapong, Letters in Drug Design \& Discovery 2013, 10, 859-864.

[8] a) G. Facchetti, I. Rimoldi, Bioorg. Med. Chem. Lett. 2019, 29, 1257-1263; b) F. Petrella, I. Rimoldi, G. Facchetti, L. Spaggiari, Expert Opinion on Therapeutic Patents 2018, 28, 813-821.

[9] a) H. Burger, A. Zoumaro-Djayoon, A. Boersma, J. Helleman, E. Berns, R. Mathijssen, W. Loos, E. Wiemer, British Journal of Pharmacology 2010, 159, 898908 ; b) K. S. Lovejoy, R. C. Todd, S. Zhang, M. S. McCormick, J. A. D'Aquino, J. T. Reardon, A. Sancar, K. M. Giacomini, S. J. Lippard, PNAS 2008, 105, 8902-8907.

[10] a) I. Rimoldi, G. Facchetti, G. Lucchini, E. Castiglioni, S. Marchianò, N. Ferri, Bioorg. Med. Chem. 2017, 25, 1907-1913; b) I. Rimoldi, V. Coccè, G. Facchetti, G. Alessandri, A. T. Brini, F. Sisto, E. Parati, L. Cavicchini, G. Lucchini, F. Petrella, E. Ciusani, A. Pessina, Biomed Pharmacother 2018, $108,111-118$.

[11] a) I. Rimoldi, G. Facchetti, E. Cesarotti, M. Pellizzoni, M. Fuse, D. Zerla, Curr. Org. Chem. 2012, 16, 2982-2988; b) D. Zerla, G. Facchetti, M. Fuse, M. Pellizzoni, C. Castellano, E. Cesarotti, R. Gandolfi, I. Rimoldi, Tetrahedron: Asymmetry 2014, 25, 1031-1037; c) G. Facchetti, I. Rimoldi, New J. Chem. 2018 42, 18773-18776.

[12] N. Ferri, S. Cazzaniga, L. Mazzarella, G. Curigliano, G. Lucchini, D. Zerla, R. Gandolfi, G. Facchetti, M. Pellizzoni, I. Rimoldi, Bioorg. Med. Chem. 2013, 21, 2379-2386.

[13] a) OECD Guideline for Testing of Chemicals-Partition Coefficient (n-octanol/water), High Performance Liquid Chromatography (HPLC) Method, 117, Adopted: 30.03.89; b) J. A. Platts, S. P. Oldfield, M. M. Reif, A. Palmucci, E. Gabano, D. Osella, J. Inorg. Biochem. 2006, 100, 1199-1207. 
[14] a) H. Brunner, M. Schmidt, H. Schoenenberger, Inorg. Chim. Acta 1986, 123, 201-207; b) Q.-P. Qin, Z.-F. Chen, J.-L. Qin, X.-J. He, Y.-L. Li, Y.-C. Liu, K.-B. Huang, H. Liang, Eur. J. Med. Chem. 2015, 92, 302-313.

[15] J. J. Wilson, S. J. Lippard, J. Med. Chem. 2012, 55, 5326-5336.

[16] V. P. Chavan, S. A. Sonawane, M. S. Shingare, B. K. Karale, Chemistry of Heterocyclic Compounds 2006, 42, 625-630.

[17] I. Rimoldi, G. Facchetti, G. Lucchini, E. Castiglioni, S. Marchiano, N. Ferri, Bioorganic \& medicinal chemistry 2017, 25, 1907-1913.

[18] N. Ferri, S. Cazzaniga, L. Mazzarella, G. Curigliano, G. Lucchini, D. Zerla, R. Gandolfi, G. Facchetti, M. Pellizzoni, I. Rimoldi, Bioorganic \& medicinal chemistry 2013, 21, 2379-2386.

[19] E. W. Raines, K. J. Garton, N. Ferri, Circ Res 2004, 94, 706-708. 